\title{
An Analysis of Illocutionary Acts of Hillary Clinton's Concession Speech to Donald Trump in Presidential Election
}

\author{
Irwandi, Muhammad Hudri, Wanda April \\ abcUniversity of Muhammadiyah Mataram, Indonesia, Irwandi@ummat.ac.id
}

\begin{tabular}{|c|c|}
\hline ARTICLE INFO & ABSTRACT \\
\hline $\begin{array}{l}\text { Keywords: } \\
\text { Illocutionary acts, assertives, directives, } \\
\text { commissives, expressives and declaratives. }\end{array}$ & $\begin{array}{l}\text { Illocutionary Acts is what the speaker wants to achieve by uttering } \\
\text { something and illocutionary acts is an utterance which has a } \\
\text { particular conventional force. with regard to this, illocutionary acts in } \\
\text { Hillary Clinton's speech is interesting to be analyzed. The purpose of } \\
\text { this research is to analyze the types of illocutionary acts found in } \\
\text { Hillary Clinton's concession speech to Donald Trump. The writer } \\
\text { used descriptive qualitative research. The main research instrument } \\
\text { was the writer herself supported by the data analysis sheet. The data } \\
\text { analysis was performed by categorizing the data based on Searle's } \\
\text { categorization of speech acts (2005) which include assertives, } \\
\text { directives, commissives, expressives and declaratives. Each category } \\
\text { was throughly observed to find the answer of the research questions. } \\
\text { The final step was presenting the data and making a conclusion in } \\
\text { reference to the findings of the research. The research findings show } \\
\text { that the types of illocutionary acts found in Hillary Clinton's } \\
\text { concession speech to Donald Trump consist of assertives, directives, } \\
\text { commissives, expressives and declaratives. Assertives have the } \\
\text { highest frequency of occurence } 13 \text { types (36.1\%). It is followed by } \\
\text { directives, commissives, expressives and declaratives which occur } 9 \\
\text { types ( } 25 \%), 3 \text { types (8.3\%), } 9 \text { types ( } 25 \%) \text { and } 2 \text { types ( } 5.6 \%) \\
\text { respectively. The dominant illocutionary acts in Hillary Clinton's } \\
\text { speech are assertives. Assertation showed the highest frequency of } \\
\text { assertives. So, the total of data were } 36 \text { types of illocutionary acts } \\
\text { founds in Hillary Clinton's concession speech to Donald Trump. }\end{array}$ \\
\hline
\end{tabular}

\section{VII.Introduction}

As social beings, people always want to relate to other human beings. They want to know their surroundings and interact with the surrounding environment. When people want to interact with the surrounding environment, they need the language to communicate. Language is foremost a means of communication. Communication always takes place within some sort of social context and integrally intertwined with our notions of who we are on both the personal and the broader, societal levels. According to Wardhaugh (2010), language is a system of vocal symbols used for human communication. When we use language, we communicate our individual thoughts, as well as the cultural beliefs and practices of the communities of which we are a part: our families, social groups, and other associations.

Language cannot be separated from Pragmatics because Pragmatics is the study about the ability to connect and also to relate the sentences and the context out of the language. In definition, Pragmatics is the study of relation between language and context that are encoded in structure of language. Another opinion from Yule (1996), pragmatics is the study of relationship between linguistics forms and the users of those forms.

Speech acts is the most interesting theory in the study of pragmatics and seems relevant in language teaching and language learning. Speech acts is an action performed by someone in saying and doing something. According to Austin (1962), there are three types of speech acts, namely locutionary acts, illocutionary acts and perlocutionary acts. A Locutionary acts is the literal meaning of the utterances. Meanwhile, illocutionary acts refers to the extra meaning of the utterance 
produced on the basis of its literal meaning and perlocutionary acts deal with the effects of the utterances on the hearer, depending on specific circumstances.

From those three acts, Yule (2014:49) states that the illocutionary acts are the most often discusses acts in pragmatics. Even, the concept of speech acts is narrowed down to the illocutionary acts and purposes the illocutionary acts based on its functions. It is according to how illocutionary acts relate to the social goals or purposes of establishing and maintaining politeness. The form types of illocutionary acts functions such as competitive, convivial, collaboratives and conflictive. So, illocutionary acts as a main analysis to analyzed Hillary Clinton's speech.

The research was conducted by Saputro (2015) entitled "The analysis of illocutionary acts of Jokowi's Speeches". In his research analyzed of two selected speeches delivered by Jokowi in APEC CEO summit 2014 Forum and World Economic Forum. Furthermore, the research focused on the types of illocutionary acts found in Jokowi's speeches, Jokowi performed such illocutionary acts viewed from the context of situation underlying the speeches and the possible perlocutionary effects of performing the dominant illocutionary acts. Meanwhile, in this study, the writer analyzed one of Hillary Clinton's speech and the writer does'nt focus on perlocutionary effect and the context of situation but, the writer focused on the types of illocutionary acts in Hillary Clinton's speech. From the previous study, the writer compare the researches above with this study as references that gives a contribution for this research.

A number of U.S media and international media called Hillary Clinton's speech as elegance and exquisit speech. Furthermore, the speech inspired suporters to get the qualified values in public and to fight for what they believe. The most important thing is that she has inspired all women of the world and new generation to build the United Stated to be better in the future. With regard to this, the writer analyze the types of illocutionary acts used by Hillary Clinton in her speech.

As the conclusion, this study discusses the following problem is what types of illocutionary acts performed by Hillary Clinton in her concession speech to Donald Trump?

\section{VIII.Method}

This study uses descriptive qualitative research. Descriptive qualitative research is a systematic subjective approach used to describe life experiences and give them meaning. Sugiyono (2016:12) states that qualitative research is a method that is used to collect the data in the form of word of pictures rather than number. In this study, the writer uses descriptive qualitative research because it can analyze systematically the fact and charachteristics of data, especially analysing the types of illocutionary acts used by Hillary Clinton in her speech to Donald Trump.

\section{A. Data Analysis}

The writer uses speech acts theory by Austin (1962) and Searle (2005) in data analysis. Data analysis is the process of systematically searching and arranging the interview transcript, field notes and other materials that you accumulate to increase your own understanding of them and to enable you present what you have discovered to others (Sugiyono, 2016:244).

The writer categorized them based on the speech acts by Austin (1962) theory about illocutionary acts and Searle (2005) theory about types of illocutionary acts which consisted of assertives, directives, commissives, expressives and declaratives. The writer observed and calculated frequency the occurence of illocutionary acts in order the data were easily read as illustrated in the following table.

Table 1. The Frequency of Illocutionary Acts found in Hillary Clinton's Speech

\begin{tabular}{ccccc}
\hline No & Illocutionary acts & Illocutionary Force & Frequency & Percentage (\%) \\
\hline 1 & Assertives & & \\
\hline 2 & Declaratives & & \\
\hline 3 & Expressives & & \\
\hline 4 & Directives & & \\
\hline 5 & Commissives & & \\
\hline & Total & & \\
\hline
\end{tabular}




\section{III.Results and Discussion}

Table 2. The Frequency of illocutionary acts found in Hillary Clinton's in her concession speech

\begin{tabular}{|c|c|c|c|c|}
\hline NO & Illocutionary Acts & Illocutionary Force & Frequencies & Precentages \\
\hline \multirow[t]{3}{*}{1} & Assertives & a. Assertion & 11 & $36.1 \%$ \\
\hline & & b. Claims & 1 & \\
\hline & & c. Conclusions & 1 & \\
\hline \multirow[t]{3}{*}{2} & Directives & a. Requesting & 3 & $25 \%$ \\
\hline & & b. Commanding & 2 & \\
\hline & & c. Suggesting & 4 & \\
\hline \multirow[t]{2}{*}{3} & Commissives & a. Offering & 2 & $8.3 \%$ \\
\hline & & b. Promising & 1 & \\
\hline \multirow[t]{4}{*}{4} & Expressives & a. Thanking & 6 & $25 \%$ \\
\hline & & b. Congratulating & 1 & \\
\hline & & c. Apologizing & 1 & \\
\hline & & d. Deplore & 1 & \\
\hline \multirow[t]{2}{*}{5} & Declaratives & a. Declaring & 2 & $5.6 \%$ \\
\hline & Total & & 36 & $100 \%$ \\
\hline
\end{tabular}

The table 4.2 above shows that the illocutionary acts found in Hillary Clinton's speech consist of assertives, directives, commissives, expressives and declaratives. Assertives have the highest frequency of occurence or 13 types (36.1\%). It is followed by directives, commissives, expressives and declaratives which occur 9 types (25\%), 3 types (8.3\%), 9 types $(25 \%)$ and 2 types $(5.6 \%)$ respectively. Furthermore, the types of assertives are claims and conclusions. The types of directives consist of requesting, commanding and suggesting. Commissives include promising and offering. The types of expressives are thanking, congratulating, apologizing and deplore. The last, the type of declaratives is declaring.

\section{VI.Conclusion}

After analyzing the data, it is important to conclude what elaborated before. This research is concerned with the pragmatic analysis of the types of illocutionary acts in reference to the Searle's categorization of speech acts (2015). So, the conclusion of this research is based on the statement of problem in this research, the writer just focused on analyzing the the types of illocutionary acts in Hillary Clinton's concession to Donald Trump in reference Searle's categorization of speech acts (2015). As the statement of problem in this research 'what types of illocutionary acts performed by Hillary Clinton in her concession speech to Donald Trump?" Then, the writer found the types of illocutionary acts, they are assertives 13 types (36.1\%). It is followed by directives, commissives, expressives and declaratives which occur 9 types (25\%), 3 types $(8.3 \%), 9$ types $(25 \%)$ and 2 types $(5.6 \%)$ respectively. The types of assertives include assertion, claims and conclusions. The types of directives consist of requesting, commanding and suggesting. Commissives include promising and offering. The types of expressives are thanking, congratulating, apologizing and deplore. Later on, the types of declaratives is declaring. So, the total of data were 36 types of illocutionary acts founds in Hillary Clinton's concession speech to Donald Trump. 


\section{References}

1. Azni, Nurul. 2011. An Analysis of Illocutionary Act in Prince of Persia : The Sand of Time Movie. Unpublished Thesis of English Department Letters and Humanities, Faculty of State Islamic, Syarif Hidayatullah University of Jakarta University. 101986-Nurul Azni WardaniFAH.pdf.

2. Budiman, Akhmad, 2011. Illocutionary Act Seen Barrack Obama's Speech. Upublished Thesis of State University of Malang. Artikel2FE829933E61D9A431FFCE65BD39486D.pdf.

3. Http://youtube.com: Hillary Clinton's concession speech to Donald Trump. Accessed on January 1st 2018 at 9.15 A.M.

4. Laurance, R. Horn \& Gregory Ward. 2006. The Handbook of Pragmatic.Oxford: Blackwell Publisher Ltd.

5. Leech, G. 1996. Principles of Pragmatics. New York : Longman.

6. Levinson, S.1983. Pragmatics. Cambridge: Cambridge University Press.

7. Mey, J.L. 1993. Pragmatics. An Introduction. Oxford: Blackwell Publisher Ltd.

8. Nadar, F.X. 2009 . Pragmatik \& Penelitian Pragmatik. Graha Ilmu: Yogyakarta.

9. Prasetyo, Eko. 2015. An Analysis Illocutionary Acts of Jokowi's Speeches. Unpublished Thesis of Graduate Program in Englisih Language Studies, Sanata Dharma University of Yogyakarta. 126332012_Full.pdf.

10. Searle, J.R.1969. Speech Acts. Cambridge: Cambridge University Press.

11. ----------1976. A Classification of Illocutionary Acts. Cambridge: Cambridge University Press.

12. -------2005. Expression and Meaning : Studies in Theory of Speech Acts. Cambridge: Cambridge University Press.

13. Sugiyono. 2016. Metode Penelitian Kuantitatif, Kualitatif, dan $R \& D$. Bandung. CV Alfabeta.

14. Suryo,Agung. 2011. An Analysis of Illocutionary Act in Sherlock Hormes Movie.Unpublished Thesis of English Department Letters and Humanities , Faculty State Islamic, Syarif Hidayatullah University of Jakarta. AGUNG SURYO NUGROH-FAH.pdf.

15. Tarigan, H.G. 2015. Pengajaran Pragmatik Edisi Revisi. Bandung: CV Angkasa.

16. Wibuwo, Destra. 2015. A Pragmatics Analysis of Illocutionary Acts in English Teaching Learning Process at SMA N 1 Wates Kulon Progo. Unpublished Thesis of English Education Program, Faculty of languages and Arts, University of Yogyakarta. SKRIPSILENGKAP.pdf.

17. www.firstladies.org: Hillary Clinton Biography, Accessed on April 1st 2018 at 07.42 A.M.

18. Yule, G. 1996. Pragmatics. Oxford : Oxford University Press. 